\title{
The Cinema of Francesca Archibugi
}

\author{
By Flavia Laviosa
}

Fall 2003 Issue of KINEMA

\section{THEMES AND MOTIFS IN THE CINEMA OF FRANCESCA ARCHIBUGI}

THE Italian cinema of the 1980s and 1990s has been characterized by a new trend labelled carineria. Enrico Magrelli defines this style as a form of creative aphasia that tries to metabolize fragments of the commedia all'italiana. He maintains that it imitates "the aesthetics of the reality-shows and talk-shows by exploiting cliché family chronicles and illustrating a catalogue of human passions" (Zagarrio 13). The carino genre has produced nice and sentimental films, criticized for revealing the contemporary directors' inability to narrate ambivalent, mysterious images or enigmatic ideas. This kind of cinema, denigrated with euphemisms such as "dignified, evasive, and promising" (Vitti 235), shows a disinterest in the exploration of the world of the soul and the mind, and insists on the complete removal of serious topics like history, politics or memory.

Critics have defined Archibugi's cinema as carino (Sesti 1994) for its inner minimalism and for producing a sort of carinismo giovanile with its youth characterizations. In fact, she chooses the family sphere as her thematic space, and, within this microcosm, she crafts the psychological traits of the disquieting nature and restlessness of her characters, who are coming of age and in search of educational role-models to emulate both inside and outside their immediate family. Parents, on the other hand, absorbed in their professional and conjugal daily routine, often offer contradictory examples. Therefore, Archibugi's carinismo speaks for her generation of parents in crisis and their children's new problematic contexts. When Mario Sesti, in the course of an interview, mentions the fact that her cinema is simple and for some critics even too simple, Archibugi replies "I make a certain type of cinema that is quite naturalistic, more than realistic [...] I am satisfied by the fact that I have established a form of communication with the audience" (Sesti 1994, 46).

Archibugi's films aim to reach many, diverse spectators, as well as achieve a wide commercial distribution. These are the reasons why she develops a personal style that adheres to a conventional cinematic realism based on popular narrative. The fact that she has consistently resisted the idea of aesthetic experimentation excludes her from the elitist circles of independent and ground-breaking filmmakers.

Among the new generation of women directors Archibugi is the only one to have produced six films, Mignon è partita, 1988; Verso sera, 1989; Il grande cocomero, 1993; Con gli occhi chiusi, 1994; L'albero delle pere, 1998; and Domani, 2000, over a period of twelve years. She is also unique in having received many awards, unanimous critical acclaim, and national and international recognition. She is currently working on her first film for Italian television funded by RAI, a free adaptation of Alessandro Manzoni's novel I promessi sposi. ${ }^{(1)}$

Archibugi has developed her own formal model: a balance between the best literary tradition of the 1800s, and the great cinematic heritage of Neorealism and the commedia all'italiana. She expresses her strong sense of belonging to the family of the Italian cinema by stating "I see myself as the great-granddaughter of Neorealism, the granddaughter of the commedia all'italiana, and the daughter of the new 1970s" (Levantesi 25). She elaborates her innovative stylistic method as an attempt to tell her stories in a realistic way as if the camera did not exist. She explains "I wanted my characters to live their own life without being mediated by cinema. I myself wished to see Italian films of this kind, where everything came out of the narrative power of the substance. I wanted characters, not sequences" (Sesti 1995, 12). Archibugi adjusts the camera angles at the children's level, and in so doing, she indicates the trajectory of their perception of the world and life expectations.

Àine O'Healy acknowledges Archibugi's reputation as an auteur of the new Italian cinema by stating that her "films, and particularly her four features set in Rome, reveal in their distinctive preoccupations and carefully considered stylistic choices, striking consistencies of vision and expression that invite an assessment of her work as that of an emerging autore" (122). When asked whether she recognizes herself in this definition, Archibugi answers with modesty "I do not know, I cannot tell you. Well, I make films that are quite personal and I always find the money to make them. These two things are expressed in what O'Healy has said about me" (Laviosa 2003, 382). Then, to the question on how she would define her cinematic signature, she replies: 
I feel that I am a person searching and I believe and hope that if something of what I have done remains at the end of my work, it will be a body of work and not only one single film. I produce several chapters of a human comedy and I do not know how to define myself. Each film is the child of the next film and these films are my own way to go through life. ${ }^{(2)}$ (Laviosa 2003, 382)

Archibugi does not presume to bring stylistic innovations, but her cinema is reliable in the narrative - a sort of fresco of urban middle-class family life, painted with the strokes of her heart.

When asked for her opinion on the claim that women filmmakers produce different cinematic genres because their value system and artistic gaze are qualitatively different, Archibugi disagrees with the idea that women's cinema reflects a gender-specific experience and sensibility or expresses feminine aesthetics. She rejects the principle that stylistic or thematic markers reveal a female presence behind the camera:

While I feel very strongly the female side in my life, I also feel that I could not be anything else than a woman. However, I think that art, in some ways, is genderless. The directors I like the most are not women. I think that in cinema there are a few explosive and strong personalities, while there are more explosive and strong personalities in literature throughout the centuries. Except for some directors like Jane Campion, Helma Sanders-Brahms, a German director and a few others, I do not think that there is a female Scorsese or a female Truffaut, even though Varda is a great director, in other words I do not think that there is a female Ozu. [...] when someone is a narrator is a narrator. Probably the greatest narrator of female characters was Ingmar Bergman, the most profound, the most knowledgeable and also the most metaphoric. Let's say that I do not like films by women that tell women's stories with a female ideology. It seems to me that this is a terrible limitation of the gaze on life, because life is made of men and women, elderly people and children, rich and poor. Therefore, a narrator cannot live within his own skin, because the narrator is gaze, a gaze on others, obviously mediated by him / herself, the narrator is an individual, an artist who watches the world and his/her gaze is not neutral. Thus, I do not recognize the idea of female aesthetics in cinema, I do not see it and I cannot find it. There are women directors whom I like very much and who depict extraordinary male portraits. A great example is Jane Campion with her remarkable male characters like the one in her film Holy Smoke!, the character of Harvey Keitel was beautifully described. In the same way there are great male directors who present wonderful female characters with comparable strength. (Laviosa 2003, 382-384)

Born in Rome in 1960, Archibugi comes from a wealthy, intellectual family and grew up in the midst of the turmoil of the 1970s. These were the years that witnessed many social and political changes for the betterment of women's conditions in the Italian family and society. The new cultural model characterized by the principles of freedom, dignity and equality, led the feminist movement to achieve a number of important socio-political reforms through major legislative changes. ${ }^{(3)}$ These were also the days of inflamed feminist battles and heated debates, animated by the powerful terms and fiery tones of the feminist rhetoric. However, this era ended after a period of about a decade and in the 1980s more informed, responsible and participatory actions took place. A sense of dissatisfaction with the political activism of the 1970s generated a thorough ideological critique and a major rethinking that led to the new approaches and strategies of the 1980s.

Archibugi's cinema can be viewed as a critical reading of her experience as a political activist in both the feminist movement and the communist party. ${ }^{(4)}$ As a daughter of a generation involved in the women's movement and inheritor of the achievements of its battles, she uses her films to distance herself from political militancy, and avoid any associations with an overtly leftist ideology.

Her work, particularly in the film Verso sera, seems to express both the pulverization of ideological expectations and the shattering of the ethical values of a generation growing up in the 1970s. The former is represented by the learned and affluent, widowed, retired, methodical and rational seventy-year-old university professor of Russian literature Ludovico Bruschi, a symbol of the historic left; the latter is personified by the exuberant, disoriented, tough, disorderly and undisciplined hippie Stella, Bruschi's daughter-in-law. A young woman from a working class family, she espouses, in an emotional and uncritical way, the cause of the youth movement in the late 1970s. These years are presented without either the justification of social reconstruction or the gratification of a moment of celebration. As symbols of failed ideologies and practices, 
both Ludovico and Stella are portrayed as defeated characters.

Archibugi's political disillusionment makes her embrace a more civic and social militancy, as expressed in Il grande cocomero and Domani. In Il grande cocomero, she denounces the overwhelming inefficiencies of the Italian national health care system, glorifying the heroic personal effort of a militant psychiatrist who devotes his life for the good of his patients. Marcello Cella claims that this film offers:

a heavy accusation against the acquiescence and complicity of a culture that has lost the reasons of its existence, [that is] the cause of those at the bottom of society who are abandoned to interested Catholic charity, [in other words a culture] without any lay alternative; [this film is an accusation] against the hypocrisy of a wordy [political] left (50).

Vitti (2003), however, argues that both the ethical message and the style of the film have little in common with the political films produced in the 1970s, the years of protest and social unrest.

In Domani Archibugi also blames Italian politicians for being inept authorities who took advantage of the disaster caused by the severe earthquake in the region Umbria in 1997 for their own gains. She gives poignant portraits of the courageous deputy mayor and the volunteers who rebuild their town without adequate state support. However, Archibugi declares:

There is no explicit denunciation against those who have forgotten the earthquake victims, not because I do not have a political heart, but, when I work on a screenplay, I find that I am more interested in relationships among the characters. It is this attention that stops me from looking elsewhere, for example to the denunciation (Perrone 2).

Domani is never rhetorical and it is animated by a moderate polemic spirit. For example, in the episode where the minister visits the town, he seems to be more concerned with the restoration of damaged art works than with people's living conditions, but Archibugi never overdoes it. Both in Il grande cocomero and Domani, her tone is not over critical towards the state run infrastructures and public administrators, because she prefers to address political issues as an integral part of family relationships and community problems.

Archibugi explores friendship, love affairs and family relationships in the life histories of people of her own generation and the next. She brings to life a polyhedral human universe, casts her poetic gaze upon a mosaic of the smallest emotions, and examines the most diverse private worlds. While hovering between comedy and civic commitment, she offers audiences carefully orchestrated films dealing with a spectrum of sociological issues relating to the new Italian familyscape.

Archibugi's debut feature, Mignon è partita in 1988, depicts the large and vital household of the Forbicionis who live under a strong emotional atmosphere of tolerance and hypocrisy. The story is narrated by the voice-over of the main character, a bespectacled thirteen-year-old Giorgio Forbicioni. He narrates from his journal the encounter with his snobbish fourteen-year-old cousin Mignon, daughter of the wealthy Parisian branch of the Forbicioni family. During her long stay in Rome, Mignon behaves as a reluctant visitor in the modest home of her uncle Federico in the Flaminio neighbourhood. Giorgio reflects retrospectively on the seismic psychological changes and the pains of growing up caused by his falling in love with her.

In 1989 Archibugi in Verso sera observes the cross-gender and cross-generational interplay in the disintegration of the family nucleus, especially when the Bruschi family's life is animated by the mother's escapes and returns, abandonment and re-appropriation of her parenting role. In this scenario of conflict and pain, Benedetti (1999) points out that adults are only partially accountable as individuals, because their responsibilities are profoundly influenced by the specific socio-cultural dynamics of the 1970s.

The story unfolds as Ludovico Bruschi's voice-over reads a yearning letter-narration that he writes to his granddaughter Papere when she turns eighteen (the year when the film is made, 1990) so that, from those notes, she could better understand her past and present as Ludovico concludes "If your mother was right or if I was right, you will probably know". This lyrical letter traces a psychological and moral analysis of Ludovico's life as a private flashback and recounts the events that took place in 1977 when his daughter and her mother stayed at his house. Oliviero, Papere's father, withdraws from the demands of the family and the stress of urban life, therefore, Ludovico and Stella hold complementary and strongly conflicting parental positions over Papere's up-bringing. Meanwhile, Papere is a little girl who lives in her own world of lively 
imagination. She sees herself split into two inseparable and distinct identities: Papera first and Papera second (which explains the plural Papere). Her perception of a double self is symptomatic of the state of anxiety caused by her parents' conflicts.

In 1993, after four years of artistic silence, Archibugi explores in Il grande cocomero the altered psyche of a young teenager whose psychological implosion generates a state of chronic neurosis. In order to counterbalance the devastating consequences of family disharmony, Archibugi gives a moving characterization of a single man, the apotheosis of the father figure, devoted to his humanitarian mission. Once again, the narration is punctuated by the main character's voice-over who types his medical journal. Inspired by the exemplar figure of the neuropsychiatrist Marco Lombardo Radice, Arturo is a brave, idealistic and passionate child psychiatrist, who struggles with Valentina (Pippi), the twelve-year-old girl affected by epilepsy, in search of a cure to her condition. Pippi is taken to the hospital after one of her periodic fits, escorted by her over-protective mother. She is visited by Arturo who immediately realizes that her pathology is the expression of a severe existential crisis. The treatment is a gradual process in which they experience highs and lows. The hospital becomes a new home for Pippi where she chooses to live. Here, she overcomes her hostility and mistrust for doctors, built over years of unsuccessful psychiatric therapies, and she manages to establish a privileged relationship with Arturo.

After the adaptation of Tozzi's novel Con gli occhi chiusi (which is not included in the analysis of this article), Archibugi ventures in more painful family situations with L'albero delle pere in 1998. Parents and children, all gravitating in the orbit of a heroine addicted mother, experience the moral and emotional destructiveness of drug addiction. The main character is the fourteen-year-old, curly-haired Siddhartha Pelosi who roves the streets of Rome on a personalized scooter during the traffic rush hours. Siddhartha is completely independent, she studies studio art at the high school, plays rock music, is a cyberfan, takes care of his mother and baby-sits Domitilla, his five-year-old half-sister. She lives with her father Roberto, an affluent lawyer, who occasionally and reluctantly lets Domitilla stay with her mother and half-brother. Siddhartha, instead, lives with his mother Silvia, a drug addict who does not work, lives by her wits, and engages in destructive relationships. Siddhartha's long-haired father, Massimo, is an alternative director of experimental videos for the television, who separated from Silvia after fifteen years of a difficult marriage destroyed by her heroin addiction.

The story is set in Rome during the Christmas holidays in 1997. Domitilla moves into her mother's home for the holidays and, like in a cruel fairy tale, pricks herself on a used needle while searching among her mother's toiletry. Siddhartha does not want to cause anguish and pain to his mother, therefore, without involving any of the adults in the family, he immediately starts an internet search. He is helped by anonymous doctors and is advised to have his sister tested for AIDS and various forms of hepatitis.

In her most recent film, Domani, released in 2000, Archibugi chronicles urban, private family dramas, placing them in a broader socio-cultural background of unresolved contrasts. She digs in the realms of the human soul, bringing out the private clashes occurring in situations of extreme tragedy, as in the natural disaster caused by an earthquake. She also uses this tragic event metaphorically to analyze the damaging shocks and aftershocks that happen within the domestic tensions of several family groups.

In Domani Archibugi leaves aside the urban Roman culture. She is the first director to tackle the aftermath of Italy's devastating earthquakes in the Umbria region in 1997 and give a choral representation of a small town struck by seismic shocks. The story describes the life of the Zerenghi family, with the father Paolo, who, as deputy mayor, takes charge of the aftermath and has the job of putting all the pieces back together. His wife Stefania who is deeply saddened by the calamity, their two children, Filippo, a tall, thin, polemic and litigious sixteen-year-old, and Agostino, an eleven-year-old, both in open conflict with their parents.

Archibugi's narrative eye lingers also on two eleven-year-old girlfriends: the impulsive Vale and the curlyhaired Tina (reminiscence of Siddhartha). Vale and Tina, who sound like "Vale[n]tina" (reminiscence of Valentina-Pippi in Il grande cocomero), one name and one person, are really inseparable. While the earthquake disrupts the town's social and family life, they react by strengthening their friendship, becoming closer and innocently more intimate. They share journals, secrets, kisses and photos from their childlike chests. The fragility of their souls is unveiled by the destruction of their homes and the precarious conditions of their lives. This ensemble drama details the friendships that grow and the relationships that change between the 
survivors of the earthquake. Vale and Tina, become estranged as their classmate Agostino chooses Tina as his girlfriend.

The films discussed in this article belong to the bildungsroman tradition. They are pedagogical films, or films of apprenticeship to life, where characters learn to grow. The moment of awakening always coincides with the time of separation. Archibugi elegantly signals that moment with symbolic and figuratively poetic scenes that seal a season of life and conclude her stories. In Mignon è partita the completion of apprenticeship is expressed in the sequence when Giorgio is running after the car which drives Mignon to the airport. He realizes that he has grown bigger and cannot get through the bars of the gate as he did when Mignon arrived - these are symbolic and graphic moments that open and end the film.

In Verso sera, the achievement of maturity is seemingly less obvious, but clearly extended to every age group. Then, whose bildungsroman is being represented? Levantesi (1995) hypothesizes that this film "is also, secretly, the bildungsroman of the grand-daughter, and it is not without meaning that she is, at age four, the first to appear [at the beginning of the film]" (33). Archibugi herself gives a hint: "In Verso sera, there is a conflict between a father-in-law and his daughter-in-law. At the beginning he seems to be always wrong, but then gradually he starts growing, while she is a character that in some ways regresses" (Laviosa 2003, 380). In this manner, Ludovico's moment of epiphany is gently expressed in his self-analytical letter for Papere when she grows up.

In Il grande cocomero, Pippi's first menstruation indicates her moment of physical maturity and psychiatric recovery, while it also suggests Arturo's sense of professional accomplishment and inner peace. They will depart after walking together to the pumpkin field.

In L'albero delle pere, Siddhartha suddenly talks with a "voce grassa" (fat voice), a sign of his physical growth as Domitilla defines it. However, his culminating moment of change and liberation is expressed in the scene where, soon after his mother's death, Massimo, Roberto and Domitilla gather to pick him up from school. While coming out of the building, Siddhartha sees his reunited family waiting for him, but he deliberately chooses to free himself from them. He therefore runs towards his lost adolescence and follows the classmate he is in love with.

At the end of the film Domani, everyone has left the village called Cacchiano, and Vale's voice-over sadly comments on the fire burning photos, journals and old memories of the days of the earthquake. The story ends with her catching a glimpse of her fully developed breasts reflected in the mirror, which indicates how much she has grown physically and emotionally since the days of her strong friendship with Tina. As Levantesi explains, "[these] characters live the formative season with restlessness and uneasiness, reaching a kind of fragile equilibrium that is neither joyful, nor final" $(1995,29)$.

Children and adolescents are cultural protagonists in Archibugi's films in the sense that these "people of few years of age", as she defines them (Sesti 1995, 10), are often victims of family situations. They experience a painful, problematic growth, they do not face infantile adversities; on the contrary, they deal with open wounds and are put in the position of growing up fast.

In her films, parents seem to have lost their authority. Archibugi, however, is not pitiless towards them. She shows empathy and solidarity mixed with subdued sadness. Her dramaturgy is never inflamed; instead, it is rather linear, steady and calm. She refuses to portray mean, cruel, dark, negative, vile, despicable characters, and she would not work "creatively with contempt or revenge" (Sesti 1995, 13). Her characters are "people who make mistakes, but have two qualities: authenticity and respect for the difference in the other" (Sesti $1995,13)$.

\section{Notes}

1. Archibugi explains in an interview with the author of this article: "This is really a special project. It is the first time that I work for television. A film for the Italian television in two episodes. It is a very personal adaptation of I Promessi Sposi (The Betrothed) by Alessandro Manzoni. It is so personal that it is not even titled Promessi sposi, but La vera storia di Renzo e Lucia (The True Story of Renzo and Lucia). So, this is my second costume drama and my second adaptation of a novel, after Con gli occhi chiusi by Tozzi. This 
film is a way to analyze feelings and relationship in a different period. It is like portraying these feelings in a more abstract, less sociological, and in some ways, purer way. I am a realistic director, I have directed all my films in Rome, in a world that I know very well. So, now I feel the need of these incursions in the past. I feel the need for a self evaluation through this film." (Laviosa 2003, 386)

2. This and other statements by Archibugi, cited in this article, are translated excerpts of an interview that she had with me in her apartment in Rome on March 16, 2002. For the full text of the interview, see Laviosa 2003.

3. The milestones of the feminist movement in the 1970s are in chronological order: 1971, Law 1204 on Protection of Working Mothers and Law 1044 on the institution of state funded day-care centres; 1974, Law 898 on the legalization of divorce; 1975, Law 151 on New Family Rights; 1975, Law 405 on the institution of socio-sanitary structures (Consultori Familiari) meant to offer protection to women's health; 1977, Law 903 on Equality in the Work Place; and 1978, Law 194 on the legalization of free and medically assisted abortion. For a detailed analysis and discussion, see Laviosa 1997.

4. Archibugi was a member of the Federazione Giovanile Comunista in 1973.

\section{References}

\section{Works Cited}

Benedetti, Laura. "Il tema dell'infanzia nel cinema di Francesca Archibugi". Women in Italian Cinema. Tonia Caterina Riviello, ed. Fabio Croce. Editore. Roma: 1999. 255-267.

Cella, Marcello. "Il grande cocomero. Dicono del film." In Francesca Archibugi. Carola Proto, ed. Roma: Dino Audino, 1995. 50-51.

Laviosa, Flavia. "1970s: a Decade of Legislative Reforms for Italian Women's Protection and Equality. "Italian Politics and Society. 47 (1997): 57-63.

Laviosa, Flavia. "Intervista con Francesca Archibugi. La famiglia post-moderna nella sua firma d'autore" Roma, Via delle Fornaci 6, 16 marzo, 2002. Incontri con il Cinema Italiano. Antonio Vitti, ed. Sciascia Editore: 2003. 375-386.

Levantesi, Alessandra. Il mio cinema emozionale. Conversazione con Francesca Archibugi. Roma, Caffè Rosati, 23 gennaio 1996. 17-37.

O'Healy, Àine. "Are the Children Watching Us? The Roman Films of Francesca Archibugi". New Landscapes in Contemporary Italian Cinema. Annali d'Italianistica. Gaetana Marrone, ed. 17, 1999. 121-136.

Perrone, Paolo. "Francesca Archibugi, cuori nel terremoto". Filmcronache 26 agosto, 2000.

Sesti, Mario. Nuovo cinema italiano. Gli autori I film e le idee. Theoria. Roma-Napoli: 1994. Sesti, Mario. "Non sono bambini, sono persone di pochi anni." Francesca Archibugi. Carola Proto, ed. Roma: Dino Audino, 1995. 10-14.

Vitti, Antonio. "Un profilo dell'identità del nuovo cinema italiano tra crisi, televisione e omologazione culturale". In Search of Italia.

Antonio Vitti, Roberta Morosini, eds. Metauro Edizioni. Pesaro: 2003. 235-256.

Zagarrio, Vito. Cinema italiano anni novanta. Marsilio Editori. Venezia: 1998.

\section{Author Information}

Flavia LAVIOSA is a Senior Lecturer in the Department of Italian Studies at Wellesley College. Her research focuses on Italian women directors. She has published on Francesca Archibugi and is currently working on 
a monograph on this director. Laviosa has also written on Cristina Comencini and the cinema produced in the Southern Italian region Apulia. 